\title{
Efektifitas Digititalisasi Marketing Para Pelaku Usaha Mikro Kecil dan Menengah (UMKM) di Lombok (Analisis Media Equation Theory)
}

\author{
Nurliya Ni'matul Rohmah ${ }^{\mathrm{a}, 1, *}$
}

${ }^{a}$ Program Studi Komunikasi Penyiaran Islam, Fakultas Agama Islam Universitas Muhammadiyah Mataram,83115, Indonesia

${ }^{1}$ nr.nurliya@gmail.com*

\section{Abstrak:}

Diterima: Juni 2019

Direvisi : Juli 2019

Ada dua permasalahan dalam penelitian ini yaitu seberapa besar interaksi para pelaku usaha kecil dan menengah (UMKM) di Lombok terhadap media pada kegiatan digitalisasi marketing menurut analisis Media Equation Theory dan seberapa efektifkah digitalisasi marketing para pelaku usaha kecil dan menengah (UMKM) di Lombok dalam pendekatan analisis Media Equation Theory. Untuk menjawab pertanyaan tersebut, peneliti menggunakan metode kualitatif dengan pendekatan analisis media equation theory untuk dapat menelaah interaksi para pelaku usaha kecil dan menengah (UMKM) di Lombok terhadap media pada kegiatan digitalisasi marketing menurut analisis Media Equation Theory dan mengetahui prosentase keefektifan digitalisasi marketing para pelaku usaha kecil dan menengah (UMKM) di Lombok dalam pendekatan analisis Media Equation Theory, peneliti menggunakan subjek penelitian para UMKM Lombok yang mengikuti kelas Gapura Digital dan Womenwill di Lombok pada tanggal 24 Agustus 2019 untuk didapatkan hasil prosentase pada indikator yang telah

Kata Kunci: UMKM

Pemasaran Digital

Teori Media Equation

Lombok ditentukan dengan memberikan link questioner yang dijawab secara online, sehingga hasil penelitian dapat langsung diketahui secara akurat.
Keywords:

UMKM

Digital Marketing

Media Equation Theory

Lombok

\begin{abstract}
:
There are two problems in this research, Which are how big is the interaction of small and medium enterprises (UMKM) in Lombok using the media in marketing digitalization activities according to the Media Equation Theory analysis and how effective is the marketing digitalization of small and medium entrepreneurs (UMKM) in Lombok in the approach Media Equation Theory analysis. To answer this question, researcher used a qualitative method with a media equation theory analysis approach to be able to examine the interaction of small and medium-sized businesses (UMKM) in Lombok to the media on marketing digitalization activities according to the Media Equation Theory analysis and find out the percentage of the effectiveness of marketing digitalization of small business and medium enterprises (UMKM) in Lombok in the Media approach Equation Theory analysis, researcher used research subjects of the UMKM of Lombok whose took the Gapura Digital and Womenwill classes in Lombok on August 24, 2019 to obtain the percentage results on the indicators that have been determined by providing a questioner link answered online, so that research results can be immediately known accurately
\end{abstract}




\section{Pendahuluan}

Dalam menjalankan bisnis, kegiatan marketing perlu dilakukan, baik itu perusahaan besar ataupun perusahaan dengan skala mikro, kecil ataupun menengah. Kegiatan marketing seperti membangun brand awareness, berinteraksi dengan pelanggan, mengedukasi pelanggan, menciptakan kepercayaan, dan menawarkan promosi atau event yang biasa dilakukan oleh pengusaha secara offline (bertemu klien langsung, menggunakan karyawan untuk menyebarkan brosur di pinggir jalan, menawarkan dagangan berkeliling dan lain sebagainya) namun saat ini justru telah menggunakan media seperti koran, radio ataupun televisi bahkan internet.

Di era digital 4.0 sekarang ini, hampir semua hal dapat dilakukan melalui satu media, yaitu Smartphone. Pemenuhan kebutuhan manusia saat ini dapat dipenuhi hanya dalam satu gengaman saja. Seperti contohnya banyak berkembangnya start-up-start-up dalam bentuk aplikasi yang banyak kita temui saat ini. Saat orang membutuhkan makan, hanya tinggal memesannya lewat handphone, memilihnya dan akan di antarkan ke rumah kita, begitu juga pemenuhan kebutuhan lain, seperti bersih-bersih rumah, massage, transportasi, sewa menyewa, jasa konsultasi, pembelajaran siswa, aplikasi sampah, toko online, beriklan dan lain sebagainya, apalagi dengan kegiatan marketing, sangat memungkinkan dilakukan secara digital pula melalui genggaman tangan kita. Kegiatan ini biasanya disebut dengan kegiatan digital marketing.

Media Equation Theory atau teori persamaan media ini ingin menjawab persoalan mengapa orang-orang secara tidak sadar dan bahkan secara otomatis merespon apa yang dikomunikasikan media seolah-olah (media itu) adalah manusia. Dengan demikian, menurut asumsi teori ini, media diibaratkan manusia. Teori ini memperhatikan bahwa media juga bisa diajak berbicara. Media bisa menjadi lawan bicara individu seperti dalam komunikasi interpersonal yang melibatkan dua orang dalam situasi berhadapan.

Menurut data dari Hootsuite, pada Januari 2019 menunjukkan dari total populasi warga negara Indonesia yang berjumlah 268,2 juta orang, 150 jutanya telah menggunakan new mass media, yaitu internet dan media sosial. Dari total tersebut pemanfaatan untuk e-commerce terdiri atas $18 \%$ fashion, $24 \%$ untuk elektronik dan media fisik, $30 \%$ untuk makanan dan kebutuhan pribadi, $23 \%$ untuk furniture, $25 \%$ untuk mainan dan hobby, $17 \%$ untuk travel dan akomodasi, dan $8,2 \%$ untuk digital musik.

Melihat data di atas, sebagai seorang pembisnis yang cerdas, mengikuti perkembangan zaman yang serba digital ini merupakan pilihan yang bijak, karena masyarakat telah banyak juga memanfaatkan digitalisasi dalam kehidupan keseharian nya, maka para wirausahan UMKM juga harus memanfaatkan digitalisasi marketing untuk pengembangan bisnisnya agar lebih besar dan lebih luas cakupannya di dunia digital. Memaksimalkan new mass media yang ada, sehingga dapat mengurangi biaya transportasi dan salary employee, namun memiliki potensi menemukan pelanggan baru, meningkatkan efektifitas kerja, mengembangkan peluang bisnis yang lebih besar. Anggap saja 1\% dari 150 juta penduduk Indonesia melihat bisnis tersebut secara online, maka sudah mencapai 1,5 juta orang yang melihat, dan bayangkan jika hanya $1 \%$ saja dari 1,5 juta orang yang melihat tersebut pada akhirnya membeli dagangannya, sudah mencapai 15 ribu orang yang kemungkinan membelinya. Potensi yang besar dan biaya yang minimal.

Keuntungan digitalisasi marketing telah dirasakan oleh beberapa pengusaha UMKM di Indonesia, terutama di wilayah Lombok. Penghasilan mereka naik hingga 80\%-200\% dari penjualan mereka secara konvensional. Alasan mereka mulai menggunakan sarana digital dalam hal pemasaran antara lain, ingin dapat menjangkau pelanggan di area lain di Indonesia bahkan sampai luar negeri, meningkatkan penjualan lebih banyak, membuka cabang tanpa harus membeli ataupun menyewa toko fisik, serta beberapa pengusaha awal yang belum memiliki toko pun, sudah mampu untuk berjualan dengan menggunakan toko online tanpa harus banyak melibatkan banyak karyawan di dalamnya. Adapun pilihan-pilihan di dunia digitalisasi untuk pemasaran go online, dapat melalui situs (web), daftar local bisnis (google my bussines), e-commerce/market place, media sosial (Instagram, facebook, youtube) serta aplikasi chat (Whatsapp, line, dll). 
Secara konseptual, media equation theory ini mencoba memberikan pandangan yang cukup menantang dan sangat baru mengenai bagaimana interaksi yang terjadi antara manusia dan media, terutama di bidang pemasaran ini. Pemetaan yang dilakukan adalah bagaimana manusia yaitu para pelaku UMKM memperlakukan media, yang dalam penelitian ini tidak diperlakukan sebagai pihak yang pasif. Media juga bisa diajak berbicara. Media bisa menjadi lawan bicara individu seperti dalam komunikasi interpersonal yang melibatkan dua orang dalam situasi face to face. Dalam teori persamaan ini, media dianggap sebagai bagian dari kehidupan nyata (media and the real life are the same).

Dari penjelasan tersebut dapat terlihat bahwa masyarakat jaman sekarang tidak selalu membutuhkan manusia untuk membantu memenuhi kebutuhannya, hal ini lah yang mendefinisikan media equation theory itu sendiri dalam kehidupan saat ini, yaitu teori penyamaan media, yang mana segala hal yang membutuhkan peran manusia, dapat tergantikan oleh media koran, radio, televisi bahkan media internet atau smartphone.

Gambarannya begini, saat kita hendak mencari lokasi toko ataupun warung, kita akan bertanya pada google untuk menunjukkan arah (Search Engine Marketing), alih alih bertanya pada teman atau warga sekitar. Contoh lain, seperti halnya para pelanggan yang memberikan komentar melalui media sosial ataupun memberikan review nya di google my business, kemudian pemilik bisnis memberikan responnya. Contoh yang lain, saat owner dan customer bercakap cakap melalui aplikasi chat (whatsapp) untuk pemesanan barang, dan lain-lain hal itulah yang merupakan bentuk komunikasi dua arah yang dimaksudkan dalam teori persamaan media ini.

Rumusan masalah dalam penelitian ini adalah Seberapa besar interaksi para pelaku usaha kecil dan menengah (UMKM) di Lombok terhadap media pada kegiatan digitalisasi marketing menurut analisis Media Equation Theory? dan Seberapa efektifkah digitalisasi marketing para pelaku usaha kecil dan menengah (UMKM) di Lombok dalam pendekatan analisis Media Equation Theory?

\section{Tinjauan Pustaka}

A. Digital Marketing

\section{1) Pengertian}

Pemasaran digital dapat dilakukan dengan berbagai cara menggunakan beberapa saluran. Adapun tujuan utama dalam proses menentukan saluran yang tepat dalam digital marketing adalah dengan memilih jenis saluran yang memberikan hasil yang maksimal pada proses komunikasi dua arah. Adapun saluran pemasaran digital itu, antara lain:
a. Pemasaran afiliasi
b. Pemasaran tampilan
c. Pemasaran email
d. Search engine marketing
e. Social media marketing
f. Hubungan masyarakat daring. ${ }^{1}$

Dalam aktivitas pemasaran digital terdapat istilah AIDA (Awareness, Interest, Desire, dan Action), khususnya dalam proses memperkenalkan produk atau jasa ke pasar (konsumen). ${ }^{2}$

\section{a. Awareness (Kesadaran)}

\footnotetext{
${ }^{1}$ J.a.F.R.Strauss. (2009). E-Marketing,5th ED. Pearson Internationa, hal 35

${ }^{2}$ Jagdish N. Sheth. (2005). International E-Marketing: Opportunities and Issues. hal 61-65
} 
Dalam ranah digital, pemilik usaha membangun kesadaran para konsumen dengan memasang iklan terlebih dahulu di media online, misalnya google ads, Instagram ads, youtube ads, facebook ads, dll.

\section{b. Interest (Ketertarikan)}

Ketertarikan terjadi, saat kesadaran konsumen telah terbangun. Jika berdasarkan sistem offline, saat kesadaran muncul, konsumen akan langsung mencari informasi di pasar. Sedangkan pada sistem online ini, konsumen mencari tahu tentang produk tersebut melalui search engine (Google), ataupun media sosial (Facebook atau Instagram).

\section{c. Desire (Keinginan)}

Saat ketertarikan telah ada, akan timbul keyakinan pada diri konsumen sehingga berkeinginan untuk mencoba produk atau jasa tersebut. Dalam sistem offline, konsumen akan langsung melakukan tawar menawar, sedangkan dalam system online akan ditandai dengan mencari keterangan lengkap tentang produk atau jasa tersebut melalui situs web.

\section{d. Action (Tindakan)}

Tindakan final, yang menentukan konsumen untuk melakukan tindakan pada produk atau jasa tersebut untuk dibeli, secara system offline, konsumen akan melakukan pembayaran, sedangkan pada system online, konsumen akan memasukkan barang dalam list pemesanan dan melakukan pembayaran secara transfer.

Digital marketing adalah kegiatan promosi baik itu untuk sebuah brand ataupun produk atau jasa menggunakan media digital. Beberapa tahun lalu, media digital marketing masih terbatas, dalam menyampaikan menyampaikan secara satu arah hanya menggunakan televisi atau radio. Namun teknologi digital saat ini berkembang sangat pesat, sehingga terjadi penerimaan yang luas dari hampir semua lapisan masyarakat, hal ini lah salah satu alasan model pemasaran digital menjadi saluran pemasaran yang utama.

Beberapa contoh teknik pemasaran yang termasuk dalam digital marketing:

\section{a. SEO - Search Engine Optimization}

Search Engine Optimization (SEO) adalah upaya penemuan website kita di mesin pencari google, bersifat organik berdasarkan alogaritma unik sehingga lebih murah karena gratis dan dapat dilakukan sendiri, namun untuk develop perusahaan membutuhkan waktu yang lebih lama karena peruntukannya sebagai investasi jangka panjang.

\section{b. SEM - Search Engine Marketing}

Search Enggine Marketing adalah upaya untuk membuat website perusahaan Anda mudah ditemukan dalam mesin pencari sejenis google dan berada di halaman pertama mesin pencari google di 4 bar teratas, dibutuhkan mendaftar google ads di google my business untuk pengapply-an nya dan berbayar.

\section{c. Media Sosial}

Beredarnya berbagai platform sosial media seperti Facebook, Instagram, Linkedin, Twitter, Youtube dan lain sebagainya, membuat penyebaran informasi menjadi lebih cepat dan menjangkau lebih banyak orang. Selain itu, sosial media marketing juga digemari karena dapat dilakukan dengan biaya minim bahkan gratis. Selain dapat meningkatkan brand perusahaan, sosial media juga dimanfaatkan sebagai sarana komunikasi dan interaksi antara perusahaan dengan konsumen.

\section{d. Periklanan online - FB ads, Google Ads, Youtube Ads dll}


Online advertising adalah media promosi atau periklanan melalui internet dengan cara berbayar. Online advertising sendiri memiliki beberapa pilihan yang beragam sesuai kebutuhan Anda, seperti Display Advertising, Social Media Advertising, PPC, Youtube Advertising.

- Promosi media cetak

- Iklan televisi \& radio

- Billboard elektronik (video tron)

- Email marketing

- Mobile marketing

- dan lain-lain ${ }^{3}$

\section{2) Keunggulan Digital Marketing Vs Konvensional}

Berbeda dengan iklan di koran, selebaran brosur dan semacamnya, pemasaran digital marketing dapat diukur secara tepat bahkan real-time.

Dengan digital marketing, pemilik usaha dapat mengetahui insight postingan iklan ataupun iklan video produk atau jasa ditonton oleh konsumen, dalam insight kita dapat mengetahui demografi konsumen, usia, gender, akses landing page, dan lain nya. Bahkan dalam sosial media, dalam insight kita dapat mengetahui hari serta jam berapa para konsumen atau follower tersebut sedang aktif.

Pemasaran digital memiliki kemampuan akan tracking, yang tentunya akan sangat membantu para pebisnis dalam menghitung ROI (return of investment) dari budget marketing perusahaannya, mengetahui berapa persen konversi penjualan dari setiap iklan yang dikeluarkan, serta dapat mengevaluasi jenis iklan mana yang baik dan tidak. ${ }^{4}$

Berdasarkan poin yang kedua, dengan adanya insight, maka akan dapat diketahui luas jangkauan geografis serta target pasar. Dengan memanfaatkan hal tersebut, pemilik usaha dapat menyebarkan konten atau brand produknya ke wilayah yang dapat disetting sesuai kebutuhan pasar bahkan sampai seluruh dunia.

Dengan keunggulan-keunggulan dari digital marketing inilah sehingga metode offline marketing atau konvensional telah banyak ditinggalkan oleh perusahaan tertentu. Adapun aset dalam digital marketing, yaitu:

- Website

- Postingan blog

- Akun media sosial

- Identitas brand (logo, company profile)

- Jejak online (review atau feedback dari pelanggan dll.)

Seperti yang sudah terlihat, bahwa website merupakan persyaratan utama untuk menang dalam persaingan digital, perusahaan akan terlihat professional jika memiliki sebuah website. Karena data menunjukkan bahwa 97\% konsumen mencari produk maupun jasa yang dibutuhkan melalui internet. $70 \%$ para konsumen mencari perbandingan harga maupun fitur yang ditawarkan dengan produk maupun jasa sejenis, dan setelah membaca review atas produk dan service dari produk dan jasa $88 \%$ para konsumen akan mengambil tindakan final untuk membelinya. ${ }^{5}$

\footnotetext{
${ }^{3}$ Desiana Andar, 11 Mei 2018. Pengertian dan Jenis Digital Marketing. https://www.seputarmarketing.com/ind/pengertian-dan-jenisdigital-marketing/, diakses tanggal 5 Agustus 2019

${ }^{4}$ Chaffey Dave, \& MayerRichard. (2009). Internet Marketing: Strategy, Implementation and Practice. Prentice Hall/Financial Times, hal 51

${ }_{5}^{5}$ Desiana Andar, 11 Mei 2018. Pengertian dan Jenis Digital Marketing. https://www.seputarmarketing.com/ind/pengertian-dan-jenisdigital-marketing/, diakses tanggal 5 Agustus 2019
} 
Website adalah "toko digital" bagi pemilik usaha yang telah menggantikan keberadaan toko fisik serta tenaga penjualan konvensional. Adapun peran utama dari website dalam ranah digital marketing sebuah perusahaan adalah:

- Menunjukkan profesionalisme perusahaan Anda

- Membantu customer memahami produk atau jasa Anda

- Sebagai "Sales Representative" 24 jam

- Media penjualan produk atau jasa Anda secara lebih mudah

- Media promosi yang lebih hemat biaya dan lebih efektif

\section{B. $U M K M$}

UMKM memiliki pengertian yaitu sebuah usaha produktif yang dimiliki oleh perorangan maupun badan usaha yang telah memenuhi kriteria sebagai usaha mikro. Seperti yang telah diatur dalam peraturan perundang-undangan No. 20 tahun 2008. Rudjito menjelaskan UMKM adalah usaha yang punya peranan penting dalam perekonomian negara Indonesia, baik dari sisi lapangan kerja yang tercipta maupun dari sisi jumlah usahanya. ${ }^{6}$

Klasifikasi UMKM (Usaha Mikro Kecil Menengah) Berdasarkan perkembangannya, UMKM di Indonesia dapat dibedakan dalam 4 kriteria, yaitu:

a. Livelihood Activities, yaitu usaha yang dimanfaatkan sebagai kesempatan kerja untuk mencari nafkah, yang lebih umum dikenal sebagai sektor informal. Misalnya adalah pedagang kaki lima.

b. Micro Enterprise, yaitu usaha yang punya sifat pengrajin namun belum punya sifat kewirausahaan. Usaha yang termasuk kriteria usaha mikro adalah usaha yang memiliki kekayaan bersih mencapai Rp 50.000.000,-, hal tersebut tidak termasuk bangunan dan tanah tempat usaha sedangkan hasil penjualan usaha mikro setiap tahunnya paling banyak Rp 300.000.000,-

c. Small Dynamic Enterprise, yaitu usaha yang telah memiliki jiwa entrepreneurship dan mampu menerima pekerjaan subkontrak dan ekspor. Usaha kecil merupakan suatu usaha ekonomi produktif yang independen atau berdiri sendiri, baik yang dimiliki perorangan atau kelompok dan bukan sebagai badan usaha cabang dari perusahaan utama. Dikuasai dan dimiliki serta menjadi bagian baik langsung maupun tidak langsung dari usaha menengah.

Usaha yang masuk kriteria usaha kecil adalah usaha yang memiliki kekayaan bersih $\mathrm{Rp}$ 50.000 .000 ,- dengan maksimal yang dibutuhkannya mencapai Rp 500.000.000,-. Hasil penjualan bisnis setiap tahunnya antara Rp 300.000.000,- sampai paling banyak Rp 2,5.000.000.000,-

Fast Moving Enterprise, yaitu usaha yang punya jiwa kewirausahaan dan akan bertransformasi menjadi sebuah Usaha Besar (UB). Usaha menengah adalah usaha dalam ekonomi produktif dan bukan merupakan cabang atau anak usaha dari perusahaan pusat serta menjadi bagian secara langsung maupun tak langsung terhadap usaha kecil atau usaha besar dengan total kekayan bersihnya sesuai yang sudah diatur dengan peraturan perundang-undangan.

Usaha menengah sering dikategorikan sebagai bisnis besar dengan kriteria kekayaan bersih yang dimiliki pemilik usaha mencapai lebih dari Rp500.000.000,- hingga Rp10.000.000.000,- dan tidak termasuk bangunan dan tanah tempat usaha. Hasil penjualan tahunannya mencapai Rp2,5 M sampai Rp50 M.

Adapun ciri-ciri dari UMKM (Usaha Mikro, Kecil, dan Menengah) antara lain:

a. Jenis komoditi atau barang yang ada pada usahanya tidak tetap, atau bisa berganti sewaktu-waktu

\footnotetext{
${ }^{6}$ https://www.maxmanroe.com/vid/bisnis/pengertian-umkm.html, diakses tanggal 4 Agustus 2019, pukul 20.55
} 
b. Tempat menjalankan usahanya bisa berpindah sewaktu-waktu

c. Usahanya belum menerapkan administrasi, bahkan keuangan pribadi dan keuangan usaha masih disatukan

d. Sumber daya manusia (SDM) di dalamnya belum punya jiwa wirausaha yang mumpuni

e. Biasanya tingkat pendidikan SDM nya masih rendah

f. Biasanya pelaku UMKM belum memiliki akses perbankan, namun sebagian telah memiliki akses ke lembaga keuangan non bank

g. Pada umumnya belum punya surat ijin usaha atau legalitas, termasuk NPWP

Seperti yang dijelaskan pada pengertian UMKM yang tertuang dalam Keppres RI No. 19 Tahun 1998 sebagai kegiatan ekonomi rakyat pada skala kecil yang perlu dilindungi dan dicegah dari persaingan yang tidak sehat. UMKM adalah pengembangan empat kegiatan ekonomi utama yang menjadi motor penggerak pembangunan Indonesia, yaitu; Industri manufaktur, Agribisnis, Bisnis kelautan, Sumber daya manusia. Pada dekade terakhir ini mulai marak bermunculan bisnis UMKM mulai dari skala rumahan hingga skala yang lebih besar. Berikut ada 3 jenis usaha yang termasuk UMKM:

\section{a. Usaha Kuliner}

Salah satu bisnis UMKM yang paling banyak dijalankan bahkan bahkan para wirausahawan muda. Berbekal inovasi dalam bidang makanan dan modal yang tidak terlalu besar, bisnis ini terlihat cukup menjanjikan, karena manusia selalu membutuhkan makanan.

b. Usaha Fashion

UMKM yang banyak diminati selain bisnis kuliner yaitu fashion. Setiap tahunnya mode trend fashion baru selalu hadir yang tentunya dimanfaatkan oleh para pelaku bisnis fashion.

c. Usaha Agribisnis

Terlihat bahwa usaha agribisnis di bidang pertanian juga mendapatkan perhatian bagi para wirausahawan untuk pengembangan bisnis. Trend sayuran, buah-buahan serta makanan organik menjadikan bisnis ini juga berjalan baik, agrobisnis tidak harus bermodalkan tanah yang luas, hanya dengan memanfaatkan perkarangan rumah dapat disulap menjadi lahan agrobisnis yang menguntungkan.

\section{Media Equation Theory}

The Media Equation Theory dikemukakan oleh Byron Reeves dan Clifford Nass lewat tulisantulisan mereka. Mereka adalah dua orang professor dari Universitas Stanford Amerika. Lewat teori ini Reeves dan Nass mencoba mempelajari hubungan komunikasi yang terjadi antara seorang individu dengan media. Reeves dan Nass mencoba menggambarkan bahwa seorang individu mampu merespon secara otomatis apa yang media itu sampaikan tanpa mereka sadari seolah-olah media tersebut adalah manusia yang bisa diajak bicara. Berdasarkan penelitian yang dilakukan oleh Reeves dan Nass, mereka yakin bahwa manusia saat ini memperlakukan media komunikasi seakan-akan mereka itu hidup dan dapat diajak bicara selayaknya manusia dan kita juga dapat merespon ada yang disampaikan oleh media tersebut. ${ }^{7}$

Media Equation Theory atau teori persamaan media adalah sebuah teori yang berusaha menjawab persoalan mengapa manusia secara tidak sadar dan bahkan secara otomatis merespon apa yang dikomunikasikan media seolah-olah media itu sendiri adalah manusia. Dengan

\footnotetext{
${ }^{7}$ Byron Reeves \& Clifford Nass, A First Look at Communication Theory, M. Griffin" Chalter 29 The Media Equation"
} 
demikian, menurut asumsi teori ini, media diibaratkan manusia. Teori ini memperhatikan bahwa media juga bisa diajak berbicara. Media bisa menjadi lawan bicara individu seperti dalam komunikasi interpersonal yang melibatkan dua orang dalam situasi face to face.

Media Equation dapat dilihat misalnya pada saat melakukan pengolahan data dengan computer, kita memerintah computer, solah-olah komputer tersebut adalah manusia. Memerintah handphone kita untuk mencarikan keinginan kita, berbicara dengan Google asistant seperti "hi Google" ataupun "Siri”. Secara tidak sadar kita berperilaku seolah-olah media itu adalah manusia.

Contoh lain dapat terlihat dalam komunikasi interpersonal, manusia saling berkomunikasi dengan manusia lainnya, belajar dari orang lain, meminta nasihat, memberikan kritik, curahan hati atas permasalahan hidup dan lain-lain, namun hal tersebut di atas dapat dilakukan oleh media massa yang secara tidak langsung menggantikan manusia.

Dalam media cetak misalnya, manusia meminta nasihat masalah-masalah psikologi pada rubrik konsultasi psikologi di media massa saat itu, bahkan mencari jodoh juga bisa melalui media, dalam rubrik kontak jodoh. Manusia bisa tertawa, sedih, iba terhadap apa yang disajikan media. Manusia bisa dikontrol oleh media dan bisa melakukan apa saja yang dikehendaki bahkan bisa jadi lebih dari itu.

Hal ini juga berlaku pada televisi. Manusia memperlakukan televisi layaknya manusia, misalnya saat sedang menonton siaran televisi dan suaranya terdengar kecil, ada kemungkinan manusia itu mendekatinya, agar terdengar lebih jelas. Jarak antara individu dengan media akan mempengaruhi perubahan emosi, sikap, dan gesture dari seseorang individu dalam merespon apa yang disampaikan oleh media tersebut.

Manusia juga bisa meniru berbagai adegan dalam televisi yang sama persis seperti yang disajikannya. Perilaku semacam ini, sama halnya perilaku manusia yang suka mencopy role modelnya, seperti anak yang mencontoh tindakan orang tuanya dan lain-lain. 8 Menurut Reeves dan Nass, ketika mesin dilengkapi dengan personality-like characteristics, orang akan merespons mesin seolah-olah benda itu punya personality. Meskipun orang-orang ini menyatakan bahwa mereka tidak percaya mesin benar-benar punya kepribadian.

Setiap individu sadar bahwa segala hal yang disampaikan oleh media baik itu berupa gambar, tulisan atau apapun adalah bukan hal yang nyata, itu semua hanya gambaran imajiner dari pesan yang hendak disampaikan oleh media tersebut. Setiap individu sadar akan hal itu dan mengatakan "Not Me" sebagai ungkapan kesadarannya, namun disisi lain individu juga merespon pesan-pesan yang disampaikan oleh media tersebut secara sosial dan alami seolah-olah gambar-gambar dan tulisan-tulisan itu nyata layaknya kita sedang melakukan interaksi interpersonal dengan seseorang. ${ }^{9}$

Menurut Reeves dan Nass, otak manusia terlibat hanya dalam aktivitas dan perilaku sosial, dan melihat semua objek yang dirasakan adalah benda nyata. Jadi dalam hal ini Reeves dan Nass mengungkapkan bahwa otak manusia cenderung akan menganggap nyata hal apapun yang dirasakannya dan meresponnya. ${ }^{10}$

Koran, Radio dan Televisi adalah media massa yang telah menggantikan manusia, namun saat ini baik beberapa peran dari koran, radio dan televisi telah tergantikan oleh new mass media, yaitu internet. Apa yang dilakukan oleh koran, radio dan televisi dapat tergantikan oleh smartphone.

Kredibilitas adalah salah satu hal yang sangat berpengaruh dalam komunikasi, seseorang akan lebih percaya atau yakin dengan pesan yang disampaikan oleh orang yang memiliki kredibilitas tinggi dibanding dengan yang memiliki kredibilitas rendah, Begitu juga dengan media, seorang

\footnotetext{
${ }^{8}$ Nurudin, Pengantar Komunikasi Massa, Rajawali Pers, Jakarta, 2007

${ }^{9}$ Ibid

${ }^{10}$ Byron Reeves \& Clifford Nass, A First Look at Communication Theory, M. Griffin" Chalter 29 The Media Equation"
} 
individu akan lebih yakin kebenaran dari sebuah pesan atau berita yang disampaikan oleh sebuah media dari pada apa yang dikatakan oleh individu lain, yang tentunya keduanya disertai dengan bukti-bukti.

Dalam teori ini Reeves dan Nass menggunakan konsep komunikasi interpersonal dari sosial psikologi bukan dari bidang komunikasi. Golongan sosial psikologi cenderung beranggapan bahwa komunikasi interpersonal adalah sebuah komunikasi one-way atau satu arah, sedangkan oleh para pakar komunikasi, komunikasi interpersonal adalah sebuah komunikasi dua arah atau two-way dimana antara individu yang satu dengan individu yang lainnya dalam sebuah komunikasi interpersonal menyampaikan dan menerima pesan secara berimbang. ${ }^{11}$

Reeves dan Nass telah menunjukkan hasil yang mengejutkan mengenai anggapan mereka bahwa media berdampak pada parallel interpersonal effects. Namun ketika media equation ini diterapkan dalam beberapa penemuan mengenai shared meanings seperti constructivism, relational dialectics, atau program penelitian interpersonal lain, teori media equation lebih seperti metaphor yang kuat daripada kepastian matematis. ${ }^{12}$

Teori Media Equation ini tentunya sangat efektif apabila diterapkan pada sebuah komunikasi massa. Lewat teori ini dimana diungkapkan bahwa keberadaan media yang dianggap selayaknya manusia yang bisa diajak berkomunikasi akan memunculkan sebuah keuntungan dalam sebuah komunikasi massa, pesan-pesan penting dengan target khalayak banyak akan mudah sekali tersampaikan apabila disampaikan lewat media-media yang tentunya juga memiliki kredibilitas tinggi. ${ }^{13}$

\section{Metode Penelitian}

Dilihat dari rumusan masalahnya, penelitian ini menggunakan penelitian kualitatif. Penelitian kualitatif adalah penelitian yang berakar pada latar alamiah sebagai keutuhan, mengandalkan manusia sebagai instrument pengumpul data, mengandalkan analisis data secara induktif, mengarah pada penemuan teori, bersifat deskriptif, lebih mementingkan proses daripada hasil, membatasi studi dengan fokus, memiliki kriteria untuk memeriksa keabsahan data, rancangannya bersifat sementara dan kesimpulan penelitian disepakati oleh peneliti dan subyek yang diteliti ${ }^{14}$

\section{A. Pendekatan dan Jenis Penelitian}

Pendekatan atau paradigma sebagai sudut pandang atau cara melihat suatu permasalahan dalam penelitian. Analisis Media Equation Theory merupakan pendekatan dan metode inti dari model penelitian yang menggunakan kualitatif. ${ }^{15}$

Peneliti menggunakan pendekatan ini untuk dapat menelaah efektifitas digitalisasi marketing para pelaku usaha mikro kecil dan menengah di Lombok.

\section{B. Subjek dan Objek Penelitian}

Sedangkan Subjek penelitiannya adalah para pelaku UMKM di Lombok (Lombok Timur, Lombok Barat, Lombok Tengah, Lombok Utara serta Mataram). Subjek penelitian merupakan peserta kelas Gapura Digital dan WomenWill Google yang dilaksanakan di Hotel Aston setiap Sabtu dan Minggu. Pada penelitian ini, peneliti mengambil sample subjek sebanyak 50 orang peserta yang hadir pada jadwal kelas tanggal 24 Agustus 2019.

Alasan pemilihan subjek ini adalah karena peneliti merupakan salah satu fasilitator Womenwill Google di Lombok.

\footnotetext{
${ }^{11}$ Byron Reeves \& Clifford Nass, A First Look at Communication Theory, M. Griffin" Cha[ter 29 The Media Equation"

${ }^{12}$ Nurudin, Pengantar Komunikasi Massa, Rajawali Pers, Jakarta, 2007

${ }^{13}$ Ibid

${ }^{14}$ Lexy J. Moleong, Metodologi Penelitian Kualitatif (Bandung; Remaja Rosdakarya, 1996), hal. 26

${ }^{15}$ Raco, J.R. 2010. Metode Penelitian Kualitatif: Jenis, Karakteristik dan Keunggulannya. Jakarta; Grasindo. hal. 56
} 
Sedangkan objek penelitian ini adalah efektifitas digitalisasi marketing para pelaku UMKM di Lombok.

\section{Tahap-Tahap Penelitian}

\section{1) Identifikasi dan Penelitian Permasalahan}

Penentuan masalah penelitian ini diawali dengan mengungkap lebih dahulu latar belakang efektifitas digitalisasi marketing para pelaku usaha mikro kecil dan menengah di NTB yang dianalisis berdasarkan media equation theory, yang dilanjutkan dengan perumusan masalah penelitian, tujuan penelitian dan perumusan hal-hal mendasar lainnya.

\section{2) Menyusun Kerangka Pemikiran}

Merupakan konsep-konsep utama yang diperlukan dalam penelitian ini. Peneliti lebih senang menggunakan teknik interview dan uji hipotesa dalam menyusun kerangka pemikiran. Hal ini dilakukan untuk panduan dalam kegiatan koleksi data sehingga data yang akan dikumpulkan benar-benar terfokus sesuai dengan permasalahan penelitian.

\section{3) Menyusun Perangkat Metodologi}

Peneliti merumuskan dan menentukan hal-hal sebagai berikut (i) pendekatan dan jenis penelitian (ii) menentukan sasaran penelitian (iii) menentukan jenis dan sumber data (iv) menentukan tahap-tahap penelitian (v) menentukan teknik pengumpulan data (vi) menentukan teknik analisis data dan teknik keabsahan data (vii) serta menentukan jadwal penelitian

\section{4) Pengumpulan Data}

Pengumpulan data merupakan inti penelitian ini, peneliti akan mengumpulkan data-data, baik itu data primer maupun data sekunder.

\section{Sumber Data dan Lokasi Penelitian}

\section{1) Sumber Data Primer}

Jenis data yang dikumpulkan untuk kepentingan penelitian ini adalah data observasi, karena peneliti ingin mencerminkan kebenaran dan kevalidan data berdasarkan dengan apa yang dilihat dan dialami langsung oleh peneliti sehingga unsur-unsur ketidakvalidan data dari sumber yang fenomenal dapat dihindari. Peneliti akan melakukan observasi langsung di lapangan serta melakukan wawancara kepada objek penelitian dan beberapa nara sumber dan juga pengumpulan dokumentasi.

\section{2) Sumber Data Sekunder}

Merupakan data tambahan atau data pelengkap yang sifatnya untuk melengkapi data yang sudah ada, seperti buku-buku refensi tentang digital marketing, UMKM, teori-teori komunikasi massa dan lain sebagainya.

\section{3) Lokasi Penelitian}

Adapun lokasi penelitiannya adalah Kelas Gapura Digital dan Womenwill Google, Pejanggik Room Hotel Aston Mataram.

\section{Penyajian dan Analisis Data}

\section{A. Ruang Lingkup Penelitian}

Hasil penelitian ini bertujuan untuk mengetahui : 
1) Interaksi para pelaku usaha kecil dan menengah (UMKM) di Lombok terhadap media pada kegiatan digitalisasi marketing menurut analisis Media Equation Theory

2) Keefektifan digitalisasi marketing para pelaku usaha kecil dan menengah (UMKM) di Lombok dalam pendekatan analisis Media Equation Theory

Berdasarkan data BPS 2006 (Sensus 2006) + WUB 31 Desember 2018 diketahui berdasarkan tabel di bawah ini:

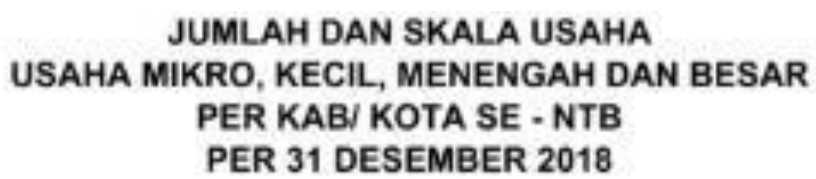

\begin{tabular}{|c|c|c|c|c|c|c|}
\hline \multirow{2}{*}{ NO } & \multirow{2}{*}{ KAB/KOTA } & \multicolumn{4}{|c|}{ KLASIFIKASI USAHA } & \multirow{2}{*}{ JUMLAH } \\
\hline & & MIKRO & KECIL & MENENGAH & BESAR & \\
\hline 1 & Mataram & 46,328 & 11,007 & 632 & 179 & 58.146 \\
\hline 2 & Lombok Barat & 110,322 & 10.286 & 461 & 34 & 121,103 \\
\hline 3 & Lombok Utara & 7.037 & 369 & 2 & & 7,408 \\
\hline 4 & Lombojk Tengah & 121.636 & 7.445 & 321 & 28 & 129,430 \\
\hline 5 & Lombok Timur & 144,029 & 16.266 & 904 & 62 & 161,261 \\
\hline 6 & Sumbawa Barat & 14,898 & 1,651 & 84 & 19 & 16,652 \\
\hline 7 & Sumbawa & 40,620 & 6.661 & 231 & 40 & 47,552 \\
\hline 8 & Dompu & 26.558 & 2.019 & 69 & 11 & 28,657 \\
\hline 9 & Bima & 48,852 & 4.535 & 107 & 17 & 53,611 \\
\hline 10 & Kota Bima & 22,267 & 2,713 & 163 & 24 & 25,167 \\
\hline & Jumiah & 582,647 & 62,952 & 2,974 & $\overline{414}$ & 648,987 \\
\hline
\end{tabular}

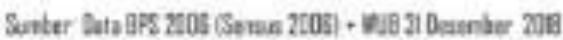

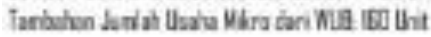

Karena luasnya cakupan serta banyaknya pada pelaku UMKM di Lombok (Mataram, Lombok Barat, Lombok Utara, Lombok Tengah, Lombok Timur) Sehingga batasan masalah pada penelitian ini, peneliti akan mengadakan survey dengan questioner online melalui google form dengan alamat http://bit.ly/mediaequation kepada para peserta kelas Gapura Digital dan WomenWill yang hadir di Hotel Aston pada tanggal 24 Agustus 2019 sebanyak 50 peserta atau bisa dikatakan 50 UMKM di Lombok.

\section{B. Analisis Media Equation Theory dalam Digitalisasi Marketing UMKM}

Berdasarkan Media Equation Theory disebutkan :

1) Individu mampu merespon secara otomatis apa yang media itu sampaikan tanpa mereka sadari seolah-olah media tersebut adalah manusia yang bisa diajak bicara.

2) Individu telah menyamakan kegunaan manusia dengan kegunaan media. Atau juga menyamakan kegunaan media dengan kegunaan new mass media.

3) Media bisa menjadi lawan bicara individu seperti dalam komunikasi interpersonal yang melibatkan dua orang dalam situasi face to face

Berdasarkan hasil questioner peneliti dengan menyesuaikan analisis media equation theory diatas, maka pertanyaan pada questioner berdasarkan hipotesa awal dibuat agar dapat membuktikan analisis teori media equation yang ada. Adapun pertanyaan dan hasil prosentase dalam questioner yang diajukan kepada subjek penelitian adalah:

1) Berapa jam anda menggunakan smartphone dalam sehari?

- $\quad<2 \mathrm{jam}=0 \%$

- $<4 \mathrm{jam}=6 \%$

- $<8$ jam $=24 \%$

- $<12$ jam $=46 \%$ 
- $\quad<18$ jam $=24 \%$

\begin{tabular}{|c|c|c|c|c|}
\hline \multirow[t]{2}{*}{ No } & \multirow[t]{2}{*}{ Pertanyaan/Pernyataan } & \multicolumn{3}{|c|}{ Interval Jawaban } \\
\hline & & $\mathrm{Ya}$ & Tidak & Mungkin \\
\hline 1. & $\begin{array}{l}\text { Apakah anda menganggap smartphone anda telah banyak } \\
\text { membantu anda dalam mengelola usaha? }\end{array}$ & $94,0 \%$ & $4,0 \%$ & $2 \%$ \\
\hline 2. & Apakah anda bekerja, mengelola bisnis anda melalui smartphone? & $94,0 \%$ & $6,0 \%$ & $0 \%$ \\
\hline 3. & Apakah anda menggunakan Google My Business? & $86,0 \%$ & $12,0 \%$ & $2 \%$ \\
\hline 4. & Apakah anda menggunakan media sosial? & $98,0 \%$ & $0 \%$ & $2 \%$ \\
\hline 5. & $\begin{array}{l}\text { Apakah aktivitas anda setiap hari banyak terbantu dengan } \\
\text { adanya Smartphone dibandingkan dengan media lain bahkan } \\
\text { manusia? }\end{array}$ & $84,0 \%$ & $6,0 \%$ & $10,0 \%$ \\
\hline 6. & Apakah anda mengatur jadwal melalui Smartphone? & $82,0 \%$ & $8,0 \%$ & $10,0 \%$ \\
\hline 7. & $\begin{array}{l}\text { Apakah anda sering berbicara dengan klien anda melalui } \\
\text { smartphone? }\end{array}$ & $92,0 \%$ & $4,0 \%$ & $4,0 \%$ \\
\hline 8. & Apakah anda mengelola team bisnis anda melalui smartphone? & $90,0 \%$ & $4,0 \%$ & $6,0 \%$ \\
\hline 9. & $\begin{array}{l}\text { Apakah anda sering meminta bantuan kepada mesin pencari } \\
\text { (google search engine) layaknya seperti manusia? }\end{array}$ & $94,0 \%$ & $4,0 \%$ & $2,0 \%$ \\
\hline 10. & Apakah anda belajar tentang bisnis anda melalui Smartphone? & $82,0 \%$ & $8,0 \%$ & $10,0 \%$ \\
\hline 11. & Apakah anda membaca berita melalui Smartphone? & $88,0 \%$ & $2,0 \%$ & $10,0 \%$ \\
\hline 12. & Apakah anda mencari resep masakan melalui Smartphone? & $78,0 \%$ & $14,0 \%$ & $8,0 \%$ \\
\hline 13. & Apakah anda mencari petunjuk arah melalui Smartphone? & $98,0 \%$ & $0,0 \%$ & $2 \%$ \\
\hline 14. & Apakah anda menonton berita melalui Smartphone? & $78,0 \%$ & $12,0 \%$ & $10,0 \%$ \\
\hline 15. & $\begin{array}{l}\text { Apakah anda mendengarkan radio atau music melalui } \\
\text { Smartphone? }\end{array}$ & $82,0 \%$ & $8,0 \%$ & $10,0 \%$ \\
\hline 16. & Apakah Smartphone sudah menggantikan fungsi koran? & $74,0 \%$ & $10,0 \%$ & $16,0 \%$ \\
\hline 17. & Apakah Smartphone sudah menggantikan fungsi radio? & $74,0 \%$ & $8,0 \%$ & $18,0 \%$ \\
\hline 18. & Apakah Smartphone sudah menggantikan fungsi televisi? & $60,0 \%$ & $20 \%$ & $20,0 \%$ \\
\hline 19. & $\begin{array}{l}\text { Apakah interaksi anda dengan Smartphone lebih banyak } \\
\text { dibandingkan interaksi anda dengan media lain? }\end{array}$ & $94,0 \%$ & $2,0 \%$ & $4,0 \%$ \\
\hline 20 . & $\begin{array}{l}\text { Apakah interaksi anda dengan Smartphone lebih banyak } \\
\text { dibandingkan interaksi dengan manusia? }\end{array}$ & $46,0 \%$ & $38,0 \%$ & $16,0 \%$ \\
\hline 21. & $\begin{array}{l}\text { Apakah mengelola bisnis online lebih efektif (dalam hal biaya) } \\
\text { dibandingkan bekerja offline? }\end{array}$ & $88,0 \%$ & $4,0 \%$ & $8,0 \%$ \\
\hline 22. & $\begin{array}{l}\text { Apakah penghasilan anda meningkat setelah melakukan digital } \\
\text { marketing? }\end{array}$ & $84,0 \%$ & $2,0 \%$ & $14,0 \%$ \\
\hline
\end{tabular}

Tabel 4.1 Angket analisis media equation theory

\section{1) Interaksi Para Pelaku Usaha Kecil Dan Menengah (UMKM) di Lombok terhadap Media pada Kegiatan Digitalisasi Marketing menurut Analisis Media Equation Theory}

Media equation theory menjelaskan seorang individu mampu merespon secara otomatis apa yang media itu sampaikan tanpa mereka sadari seolah-olah media tersebut adalah manusia yang bisa diajak bicara. Hasil penelitian membuktikan bahwa:

a. Para pelaku UMKM 94,0\% telah menganggap smartphone banyak membantu dalam mengelola usaha

b. Para pelaku UMKM mengatakan bahwa aktivitas mereka $84 \%$ menggunakan smartphone dibandingkan dengan manusia

c. Para Pelaku UMKM 92\% nya berbicara dengan klien melalui smartphone

d. Para Pelaku UMKM 94\% meminta bantuan kepada google search engine layaknya seperti manusia

e. 46\% mengatakan "ya" pada interaksi dengan smartphone lebih banyak dibandingkan interaksi dengan manusia dan 16\% nya mengatakan "mungkin", dan hanya $38 \%$ saja yang mengatakan "tidak". 
Media Equation Theory menjelaskan bahwa individu telah menyamakan kegunaan manusia dengan kegunaan media. Atau juga menyamakan kegunaan media dengan kegunaan new mass media, hal ini dibuktikan dengan hasil penelitian bahwa 94\% para pelaku UMKM mengelola bisnis menggunakan smartphone, $86 \%$ dari mereka telah menggunakan media sosial, $82 \%$ dari mereka mengatur jadwal melalui smartphone, $82 \%$ belajar bisnis melalui smartphone, $82 \%$ mendengarkan radio atau music melalui smartphone, smartphone $74 \%$ bagi mereka telah menggantikan fungsi koran, smartphone $74 \%$ telah menggantikan fungsi radio, dan $60 \%$ smartphone telah menggantikan fungsi televisi.

Poin yang terakhir dari media equation theory adalah media bisa menjadi lawan bicara individu seperti dalam komunikasi interpersonal yang melibatkan dua orang dalam situasi face to face, hal ini dibuktikan dengan 90\% para pelaku UMKM mengelola team bisnis tidak dengan rapat offline, tapi justru menggunakan smartphone. $88 \%$ dari mereka mengatakan dapat mengelola bisnis secara efektif justru dengan menggunakan smartphone dan hanya $4 \%$ saja yang melakukannya secara offline.

Keefektifan digitalisasi marketing para pelaku usaha kecil dan menengah (UMKM) di Lombok dalam pendekatan analisis Media Equation Theory

Ekonomi saat ini memaksa setiap orang untuk mencari penawaran terbaik yang bisa mereka temukan, dan biasanya penawaran lebih banyak ditemukan di internet. Pemasaran digital membantu perusahaan untuk meningkatkan eksposur kepada konsumen yang aktif mencari produk atau jasa, sehingga jauh lebih efektif daripada bentuk-bentuk lain dari iklan. Meningkatkan eksposur perusahaan melalui pemasaran digital seperti memberikan para konsumen yang selalu lapar mencari kebutuhan mereka secara mudah di dunia digital.

Dari hasil survey ditemukan, bahwa pada pelaku UMKM menunjukkan bahwa 84\% dari mereka penghasilannya telah meningkat setelah melaksanakan kegiatan digital marketing untuk usahanya.

Sementara itu, Pasca gempa Lombok yang terjadi di tahun 2018 lalu, perekonomian di Lombok menurun drastis, sehingga dibutuhkan sebuah gerakan digital bagi Lombok untuk bangkit kembali dalam hal perekonomiannya.

Untungnya, Google memutuskan untuk memilih Lombok sebagai salah satu dari 14 kota pilihan untuk bisa diberikan kesempatan kelas digital gratis setiap minggunya kepada para UMKM, dan telah mentraining para pengusaha kecil di Lombok melalui program Gerakan Pelatihan Usaha Rakyat (Gapura) Digital dan WomenWill, yang mana melalui program ini akan membantu para UMKM di Lombok dalam peningkatan bisnis mereka melalui Google My Bussiness sehingga usaha mereka dapat terlihat di Google Maps, sehingga dapat ditemukan oleh para pelanggan baru, dan menonjol serta beberapa modul lain yang menunjang bisnis mereka.

Ibu Lelly Farida, owner dari Rinjani Garden menuturkan:

"Setelah saya mengikuti kelas Google, dan saya menggunakan Google My Bussiness, dan selalu mengupdatenya, kami mulai kedatangan tamu lagi, yang bukan tamu agen, itu kalau kami Tanya "tahu dari mana tempat kami? Karena kan tempat kami lumayan nyempil, jauh dari jalan besar, lalu mereka jawab, tahunya dari Google maps".

Ibu Indah Trisnawati, Owner Lombok Orchid memberikan penuturannya:

"Perbandingan bisnis dari sebelum dan sesudah menggunakan Google my Bussiness, perbandingannya lumayan signifikan, meningkatnya lumayan jauh., karena ternyata bagus banget, dan fiturnya sangat membantu para UKM di Indonesia, fitur yang sangat bermanfaat dalam menggunakan Google my Bussiness, pertama kita bisa melihat review dari pelanggan-pelanggan kita dan merespondnya dengan baik, terus yang kedua kita bisa melihat, pembeli itu mencari kita itu dari mana sih, lewat browser atau telpon kah atau dari mesin pencarian Google, menurut saya review dari para pelanggan sangat berguna, karena itu meningkatkan kepercayaan bagi pelanggan 
baru atau pembeli lain untuk beli di kita. Jadi, sebelum mereka belanja, mereka kepo dulu tuh, apa benar sih Lombok orchid itu bagus dan disitu review-review itu sangat bermanfaat."

Begitu juga juga dituturkan oleh Ibu Sherly Shanty, owner Rumah Durian Lombok:

"Perkembangan bisnis pada saat belum menggunakan google my bussines memang berkembang, tapi ya segitu-gitu ajah, karena kami berjualan masih menggunakan system tradisional. Akhirnya saya belajar untuk melek digital dengan mengikuti kelas Womenwill dan Gapura Digital, dan bisnis saya pun naik secara signifikan"

\section{Kesimpulan}

Manusia saat ini, di era digitalisasi sekarang ini terbukti telah memperlakukan media seperti layaknya manusia. Mengajak media berbicara seperti yang dilakukan manusia dengan google assistant untuk menanyakan apapun, mulai dari lokasi tertentu hingga cuaca bahkan dapat melakukan tebak-tebakan juga dengan mesin assistant google. Para UMKM mengelola bisnis serta team juga menggunakan media, berinteraksi dengan pelanggan, rapat secara online, mengatur jadwal, menonton televisi, mendengarkan musik dan radio, bahkan membaca buku dan koran mereka telah menggunakan media, alih-alih bertemu dengan klien secara langsung secara table talk, atau membaca koran secara langsung, atau menonton televisi secara langsung ataupun radio secara langsung. Semua telah disamakan, dan cukup menggunakan satu media untuk memenuhi segala kebutuhannya, yaitu smartphone. Sehingga realita yang terjadi dianalisis, yang dalam hal ini sesuai dengan teori media equation itu sendiri

\section{DAFTAR PUSTAKA}

Byron Reeves \& Clifford Nass, A First Look at Communication Theory, M. Griffin" Cha[ter 29 The Media Equation"

Chaffey Dave , \& MayerRichard. 2009. Internet Marketing: Strategy, Implementation and Practice. Prentice Hall/Financial Times

J.a.F.R.Strauss. 2009. E-Marketing,5th ED. Pearson International

Jagdish N. Sheth. 2005. International E-Marketing: Opportunities and Issues

Lexy J. Moleong, 1996, Metodologi Penelitian Kualitatif (Bandung; Remaja Rosdakarya,

Nurudin, Pengantar Komunikasi Massa, Rajawali Pers, Jakarta, 2007

Raco, J.R. 2010. Metode Penelitian Kualitatif: Jenis, Karakteristik dan Keunggulannya. Jakarta; Grasindo

\section{Website Link}

Desiana Andar, 11 Mei 2018. Pengertian dan Jenis Digital Marketing. https://www.seputarmarketing.com/ind/pengertian-dan-jenis-digital-marketing/, diakses tanggal 5 Agustus 2019

https://www.maxmanroe.com/vid/bisnis/pengertian-umkm.html, diakses tanggal 4 Agustus 2019, pukul 2019 